\title{
MEDIATING ROLE OF ETHICAL LEADERSHIP BETWEEN EMPLOYEES EMPOWERMENT AND COMPETITIVE EDGE: A CASE OF COMMERCIAL BANKS IN PAKISTAN \\ Muhammad Azizullah Khan ${ }^{1}$, Mahboob Ullah ${ }^{2 *}$ \\ ${ }^{1}$ Associate Professor, Preston University, Islamabad, Pakistan; ${ }^{2^{*}}$ Associate Professor, Department of Management Sciences, Khurasan University, Nangarhar, Afghanistan. \\ Email: "mahboobmails@gmail.com
}

Article History: Received on $23^{\text {rd }}$ March 2021, Revised on $5^{\text {th }}$ April 2021, Published on $6^{\text {th }}$ April 2021

\begin{abstract}
Purpose of the study: The current study aimed to examine the impact of employee empowerment on reaching a better level of competitive edge through the mediating influence of ethical leadership.

Methodology: Dimensions of competitive edge were employed, including (quality, responsiveness, innovation, and efficiency). A quantitative approach was adopted to attain the main objective of the study. A questionnaire was employed to collect data from 258 individuals' of Pakistani commercial banks. SPSS/ AMOS was used to screen and analyze the gathered data. Cronbach's Alpha was used to test the reliability of the study tool. Multiple regression analysis was performed to test the hypotheses of the study. Preacher and Hayes model was deployed to test the mediation effect.
\end{abstract}

Principal Findings: The study's results indicated that ethical leadership mediates the relationship between empowerment and competitive edge. Besides, the study highlighted that ethical leadership influences empowerment in a way that leads to better efficiency and service quality, launching from leaderships' role in increasing awareness of service quality importance and leading employees towards being more creative and innovative.

Application of this Study: The study recommended that workers in the bank sector should submit proposals that affect skills training and the expansion of their fields of empowerment in comparison with the previous stage and offer workers with proven skills a chance to engage in decision making to strengthen their skills and provide them with the ability to learn further in the field of banking.

Novelty/Originality of this study: This is the first study that has analyzed the mediating role of ethical leadership between employees' empowerment and competitive edge in the context of listed Pakistani commercial Banks.

Keywords: Ethical Leadership, Employees Empowerment, Competitive Edge, Commercial Banks.

\section{INTRODUCTION}

In this universe, the only constant thing is change. Maintaining the status quo is no longer a realistic alternative for companies. In today's dynamic business climate, effective and consistent creativity is vital to an organization's sustainability. The ever-changing market landscape forces companies to see creativity as a means of growth, production, and long-term viability. Individuals' ideation and execution of innovations provide a company with a strategic edge. Organizations are ready to examine any causes that can improve workers' creative job behavior (Andi Kele, 2020; Bavik et al., 2018).

In today's turbulent and multinational landscape, the deepening competition is mainly marked by technical innovation, which is also difficult for any enterprise. Similarly, individual firms working in these turbulent markets must be able to reinvent themselves by creative methods to preserve their viability and sustainability. In the face of fiercer competition and rising environmental instability, the potential to evolve has become increasingly necessary as a means of survival and promoting development (Ullah, Afghan, Afridi, 2019). Similarly, in the twenty-first century, creativity is essential for an organization's economic growth and long-term viability. As a result, such a corporation would go to whatever extent to enhance their ability to build creative ecosystems to retain their competitive advantage. In the financial industry, the same thing happens. It is undeniable that creativity is a large and complex area of study. The thinkers before them attempted to comprehend creativity in a variety of respects.

Despite the slight overlap of such definitions and hypotheses, this research centered exclusively on implementing employee empowerment, which has become particularly relevant in knowledge-intensive companies. Employee empowerment centers on enhancing the efficiency of products/services and systems that can be used to develop new products/services or enhance existing ones' performance. Nowadays, the only consistency is uncertainty; leadership and information management are two of the most often cited vital competencies that can improve workers' success in a fastpaced market environment. To achieve its pre-determined strategic goals, an organization requires a successful leader.

In reality, no company can accomplish creativity without employee involvement (Jocelyne and Kariuki, 2020). Along with the importance of creativity, scholars have long recognized the importance of leadership in focusing and directing individual imaginative and inventive activities toward overall organizational innovation (Andi Kele (2020). Leadership has faced new obstacles as market environments have evolved. One crucial development in this regard is organizations' emphasis on human capital. As a result, academics began to investigate ethical leadership, a leadership model that 
prioritizes workers' needs. Both academics and professionals emphasized the need for a more people-centered leadership model, forcing leadership experts to reconsider compassionate leadership styles such as ethical leadership (Bavik et al., 2018). Organizations that want to foster creativity should look for executives who will empower and champion their workers' vision. Ethical leaders prioritize the career and personal advancement of their supporters, inspiring them to give their all. Researchers are also looking at the impact of ethical leadership on workers' imaginative and innovative behavior (Andi Kele (2020; Bavik et al., 2018).

According to a critical analysis of the scientific literature, there are only a few findings on the interaction between ethical leadership and employee empowerment (Minbaeva, 2018; Ullah, Afghan, Afridi, 2019; van Dierendonck, \& Liden, 2018). As a result, it is strongly justified to examine the effect of ethical leadership on employee empowerment in the presence of multiple mediating/moderating variables. Furthermore, this is one of the first studies to look at the impact of ethics at various employee empowerment stages.

Obtaining a competitive advantage for market entities of all kinds has become a highly coveted aim that they aspire for, in reaction to the demands of the globalization and transparency age, which necessitates the introduction of new administrative structures that lead to workplace crises and challenges (Minbaeva, 2018). As a result, companies have prioritized human capital, management, guidance, and inspiration over other concerns such as budgets, infrastructure, and organizational processes, as it addresses problems such as innovation, commitment, belonging, engagement in decisionmaking, freedom at work, and trust in success. As a result, interest in the concept of employee empowerment became a vital component of these organizations' success.

Studies have been proved that an ethical leader is a successful leader. Via two-way open dialogue, participatory decisionmaking, affirmation, and ethical leader models normatively acceptable norms and reinforces them to their subordinates. Followers are allowed to share their concerns and views in this situation publicly, and their ideas are respected and genuinely listened to. As a consequence of such ethical actions, subordinates are likely to be motivated to change current work systems, practices, and techniques by creating and developing new concepts. Ethical leaders should also allow their workers more significant influence and control during the decision-making process, allowing followers the independence and power to do their work creatively. As a result, new solutions may be proposed, marketed, and adopted within a knowledge-intensive enterprise with ease. As a result, ethical leadership has emerged as an essential source of employee empowerment and strategic advantage in the banking sector. As a result, this study investigates the effect of employee empowerment on achieving a higher degree of competitive advantage through the mediating influence of ethical leadership.

This study is developed in the following structure; The theoretical framework of the variables under discussion will be explored in greater detail in the next section. Hypotheses are first formulated based on theoretical and empirical data, supported by pictorial representations of conceptual structures. The research methodology is then presented, accompanied by the section on findings and discussion. Finally, the study ends with a review of the conclusions, their theoretical and functional implications, and the study's limitations and future research directions.

\section{AIM AND OBJECTIVES}

The current study aimed to examine the influence of employee empowerment on the competitive edge by focusing on the mediating effect of ethical leadership of listed commercial banks of Pakistan. From this aim, the following question arises:

\section{How ethical leadership mediates the relationship between employee empowerment and a more enhanced competitive edge?}

To answer the aforementioned main questions, the given below sub-questions are developed;

- How can employee empowerment be a driver to a better competitive edge in an organization?

- What is the relationship between empowerment and ethical leadership?

- Can ethical leadership support a better competitive edge for the organization through focusing on empowerment?

\section{LITERATURE REVIEW}

\section{Employee Empowerment}

Empowerment involves empowering people to give their skills and duties, inspiring them to take the correct decisionmaking, and giving them independence and trust to do their jobs without overt management intervention (Yin, 2020). About Bani-Melhem et al. (2020), employee capacity is designated as the consolidation of management and workers' relationships, motivation, participation in decision-making, and the breaking of internal administrative and organizational blockades between management and workers.

Andi Kele (2020) says that the concept of empowerment is founded on a higher management authority and trust that employees will openly fulfill their tasks, leading to a climate of comfort and value, growing accountability, and generating a positive attitude among workers is a significant motive for work. The theme of empowerment (Jocelyne and 
Kariuki, 2020).

The authorization gives workers the confidence needed to develop the resources they need to control the job, according to Sulaiman and Muhamad (2020). From Obi's (2020) perspective, empowerment was found to be the sharing of authority and responsibilities by their delegation to various levels within the organizational framework, while Khan et al. (2020) considered empowerment as knowledge sharing, improving organizational frameworks, reinforcing teams, inspiring and empowering people to change initiatives and embrace risks.

Empowerment is generally a transition of responsibilities and control from management to junior staff and an opportunity to participate in the decision-making process (Andika and Darmanto, 2020). Al-Otoom (2009) argues that empowerment allows employees the right to take action through ingenuity and accountability and successful involvement in the management of their organizations.

\section{Dimensions of Empowerment}

Empowerment, in its different concepts, is based on a set of dimensions mentioned by Kahreh et al. (2011), Jocelyne and Kariuki (2020), Kiyabo and Isaga (2020), Khan et al. (2020), and Ullah, Afghan, Afridi (2019) and they are represented in the following:

\section{Development of creative behavior}

In public organizations and educational organizations, in particular, creativity is an essential element. The affirmation of appropriate ways to carry out the work is recognized. The imaginative choice is the decision that leads to new ways of seeing solutions to the dilemma.

\section{Delegation of authority}

Authority centralization is measured by the extent to which upper management delegates it to lower levels. The aim is to entrust responsibility and powers to someone else to perform a specifically specified role and to assign certain powers that the leader has derived from the legislation to one of the staff at successive administrative levels, given it is a mechanism for him to determine which knows the need to return to the head.

\section{Mimicry and simulation}

Behavior simulation, a study of personal discrimination, offers the worker generation to imitate and simulate the behavior of people who respect them. Simulation is considered the essential means of developing skills and changing behavior.

\section{Teamwork}

Work is a group of individuals forming an integrated organizational structure that shares the objective and a specific difference in the work's comprehensiveness between the working team and the group. As part of the corporate process, the team is responsible for executing the mission and meeting the goal in the job power.

\section{Self-motivation}

The analysis of benefits is a way to be able to meet employees' desires. Suppose you see leadership in enhancing their employees' competitiveness and performance. In that case, it must recognize its causes and improve its needs and provide them with adequate resources to inspire them to act as they wish.

\section{Competitive Edge}

According to Mahasneh et al. (2020), the principle of competitiveness is considered a true breakthrough in the field of academic and science management. Academically, leadership is no more seen as an internal concern or a fleeting conflict with issues that are not strategic but as a complex and continuing mechanism aimed at dealing with multiple external or internal challenges for the company, vendors, customers, and others to achieve consistent excellence (Rashid et al., 2019).

Rashid et al. (2019) look at the competitive edge as the organization's ability to develop new methods that are more effective than those used by competitors. It can embody this discovery in the field simply by creating a creative process in its broad sense. As for Kiyabo and Isaga (2020), the competitive edge was seen as an element of the organization's superiority achieved if it follows a specific strategy to compete. On the other hand, Duffett et al. (2018) defined competitive edge as the organization's ability to fulfill the consumer's needs or the value obtained from that product, for example, the short supply period or the high quality of the product.

Through the definitions, it is concluded that a competitive edge is the ability to fulfill consumers' desires. The consumer is the judge in the market, so satisfying customers is the primary goal that the organization seeks to achieve (Al-Qershi et al., 2020). From that, it can be said that competitive edge means providing products distinct from what the competitors offer in the market and satisfying customers in a different or more than them Economic corporation achieving a competitive advantage by developing a competitive strategy based on the results of internal analysis of the surrounding environment (Altarawneh, 2017). 


\section{Dimensions}

Competitive edge is based on the existence of several dimensions that together constitute the implicit meaning of competitive edge, which are:

\section{Cost}

Organizations seeking to achieve a more significant market share as the foundation of their success and dominance are those who sell their goods to their competitors at a cheaper cost. Cost reduction is the principal organizational objective of competitive companies (Rahim et al., 2019). They even want to cost low prices of the goods manufactured by firms that operate on competition boundaries (Kalashi et al., 2020). Management operations aim to reduce manufacturing costs against rivals and achieve sustainable pricing that improves goods' competitive advantage (Hurmelinna-Laukkanen et al., 2018).

\section{Quality}

Cantele and Zardini (2018) claim that quality is a significant competitive advantage, which shows how things go well to have goods that meet customers' needs; customers want products with quality that satisfy their requirements, which are what they predict or see in the publicity (Seyyed-Amiri et al., 2017). Organizations that do not provide goods that meet the consumers' needs and wishes cannot prosper and prosper in competitive behavior (Amer and Abdulwahhab, 2020).

\section{Flexibility}

Flexibility is the foundation for achieving the organization's competitive advantage by adapting rapidly to shifts in product growth that satisfy consumer needs (Kusumadewi and Karyono, 2019). Flexibility ensures that the company can shift operations differently, which means changing operating efficiency, and changing its process and time (Tsai and Lin, 2018).

\section{Delivery}

According to Minbaeva (2018), distribution is the basic rule for competition between business organizations by concentrating on reducing lead times and speed in designing and displaying new goods to consumers as quickly as possible. The distribution component has three factors: delivery pace, delivery on schedule, production speed (Bharadwaj et al., 2017).

\section{Innovation}

Some writers and researchers add creativity as a dimension of competitive edge Al- Zwaylif and Taher (2020); Mohammed et al. (2019; Saeidi et al. (2020); . The opinions of writers and researchers on innovation have varied. There are many definitions of creativity. Chengwu (2020) defined it as the process or activity that an individual performs and produces something new. As for creativity, Kaleka and Morgan (2017) represent the product of valuable ideas and the ability to adopt these ideas and put them into practice.

\section{Ethical Leadership}

The fundamental changes that occurred under different organizational and environmental circumstances have made organizations aware that it is necessary to have leadership abilities that promote and enhance the imagination of employees (Feng et al., 2019) and to leaders who believe in creativity to achieve creative energy (Yang and Wei, 2017) (Javed et al., 2018). Ethical leadership stemmed through various years of intensive studying and analyzing what leadership means and the core of ethics (Duan et al., 2018). As a start, ethics are defined by many scholars and researchers as the principles that govern human behavior and activities (Asif et al., 2019), (Jones et al., 2018) and (Engelbrecht et al., 2017). With the course of time and the continuous studying of various statuses of leadership, there appeared the so-called ethical leadership which was defined by Zhao and Xia (2019) as acting according to ethical principles in leadership work and decision-making, that is, doing the right thing in all situations and situations. From another perspective, Pasricha et al. (2018) defined ethical leadership as adhering to moral principles at work, taking into account differences in viewpoints, and working to settle disputes in the workplace in a fair manner for all parties.

According to Yeșiltaș and Tuna (2018), leadership that relies on defining moral goals and values is necessary for internal harmony in organizations and maintaining their competitiveness in the market, and preserving stakeholders' rights. Ethical leadership, according to Dust et al. (2018) is the making of collaborative personal decisions through the formation of a belief in shared understanding, the possibility of success, complete satisfaction with personal motives, and the integrity of the common goal. Hence, the organization's vision, mission, and Wahyuningsih et al., 2019 values are an essential part of leadership.

\section{Employee Empowerment is a Driver of Better Competitive Edge}

Empowering employees means directing them towards effective decision-making by linking their interest to the validity of that choice, that is, having an incentive to convince individuals that making the right decision will not only be of benefit to the organization but also benefit them (Ullah, Afghan, Afridi, 2019). Besides, Kadhim et al. (2018) have 
indicated that empowering employees contributes to raising the level of competitive edge by increasing the status of their loyalty to the organization and thus affecting their performance and decisions to reach the right decision is in the interest of the organization.

Safari et al. (2020) indicated that there are many positive effects of empowerment on the organizations' competitive edge by creating a kind of trust between employees and departments and thus pushing workers towards achieving the desired goals based on the idea that the belief that was made between the organization and its employees, therefore, employees have to adhere to the standards and grounds of this trust by increasing the level of effectiveness in their work, concern for the level of quality in providing service, responsiveness for customers and responding to their requirements in addition to creativity and innovation in theirdecisions, and this is also agreed upon Gautam and Ghimire (2017).

\section{Ethical Leadership Supports Employee Empowerment}

Empowerment methods differ according to the nature of the organization, the source of empowerment, the extent of management awareness of the importance of empowerment, and many differences associated with the skills and experience of working individuals (Al-Zoubi, 2012). Among the methods of empowerment is empowerment through leadership, where the empowerment of subordinates is one of the modern leadership styles that contribute to increasing the effectiveness of the organization (Phangestu, 2020). Khan and Anjum (2013) indicated that empowerment through leadership is based on the leader's role in empowering workers and delegating powers or authorities from top to bottom. Increased after new management strategies, which include ideas like intellectual capital and strategic management, rely on organizations to apply them in ways that go along with these changes, such as implementing total quality management and learning organizations (Bello, 2012).

As for Javed et al. (2017), it was indicated that empowering employees through leadership, especially ethical leadership, contributes to the emergence of cognitive factors for the individual by directing them towards acceptance of responsibility and independence in decision-making, meaning that employees who are empowered by their leaders' support have greater levels of control over job requirements, and more remarkable ability to invest information and resources at individual levels (Bavik et al., 2018).

\section{MODEL AND HYPOTHESES}

Based on the above argument, the researcher was able to extract a set of hypothesis from the following relationship between variables:

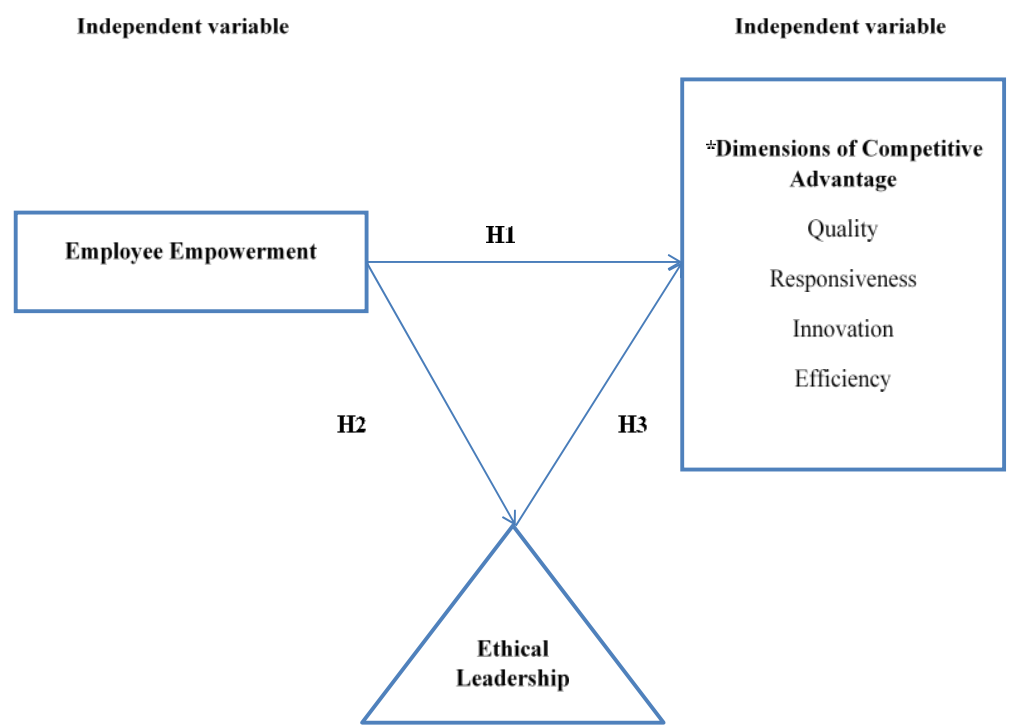

Figure 1: Study Model (Al-Otoom 2009; Kahreh et al. 2011; Kiyabo and Isaga 2020)

\section{RESEARCH HYPOTHESES}

$\mathbf{H}_{1}$ : Employee empowerment can influence competitive edge.

$\mathbf{H}_{2}$ : Employee empowerment can influence Ethical Leadership.

H3: Ethical Leadership can influence competitive edge.

H4: Ethical leadership mediates the relationship between employee empowerment and competitive edge. 


\section{METHODS}

Realizing the aim and objectives of the current study was done depending on a descriptive quantitative approach. A description was presented tackling the study variables and the previous literature, which pointed out the nature of the relationship between them. The quantitative approach was then adopted depending on a questionnaire; the questionnaire consisted of two main sections. The first section took into perspective the demographic statistics of the sample. The other section presented statements related to variables of study that included independent variable, dependent variable, and the mediating variable. The final copy questionnaire consisted of (34) statements distributed on study variables and built on Likert 5 scale ( 5 strongly agree, 4 agree, three neutral, 2 disagree, and one strongly disagree).

The study population consisted of managers within Pakistani commercial banks; a sample was chosen to represent the population in total of (300) individuals as a convenient sample. SPSS/ AMOS was used to screen and analyze the gathered data; after the application process researcher was able to retrieve (258) adequately filled questionnaire, which indicated a response rate of $(86 \%)$ as statistically accepted.

Cronbach's Alpha was used to test the reliability of the study tool, and the reliability test resulted in a value of (0.934) for all the items within the study, the Alpha, however, resulted in greaterthan 0.60, which indicated the tool consistency that enhanced its use in the study.

\section{ANALYSIS AND DISCUSSION}

\section{Demographics Analysis}

Frequency and percentage were highlighted within the following table to highlight respondents' answers to the questionnaire as per demographic variables. It appeared from the analysis that the majority of individuals who responded to the questionnaire were (male) with a percentage of $(65.9 \%)$ compared to (females) who appeared to represent only $(34.1 \%)$ of the total sample. As for age range, it was found out through analysis that most respondents were within the age range of (36-41) years old, forming (37.6\%) of the total sample. (M.A.) holders seemed to have the majority in representing the sample forming $(62.4 \%)$ of a total sample. In comparison, the experience seemed to go for those who had an experience of (12-15) years forming (38\%) of the total sample.

Table 1: Sample Characteristics according to Demographics

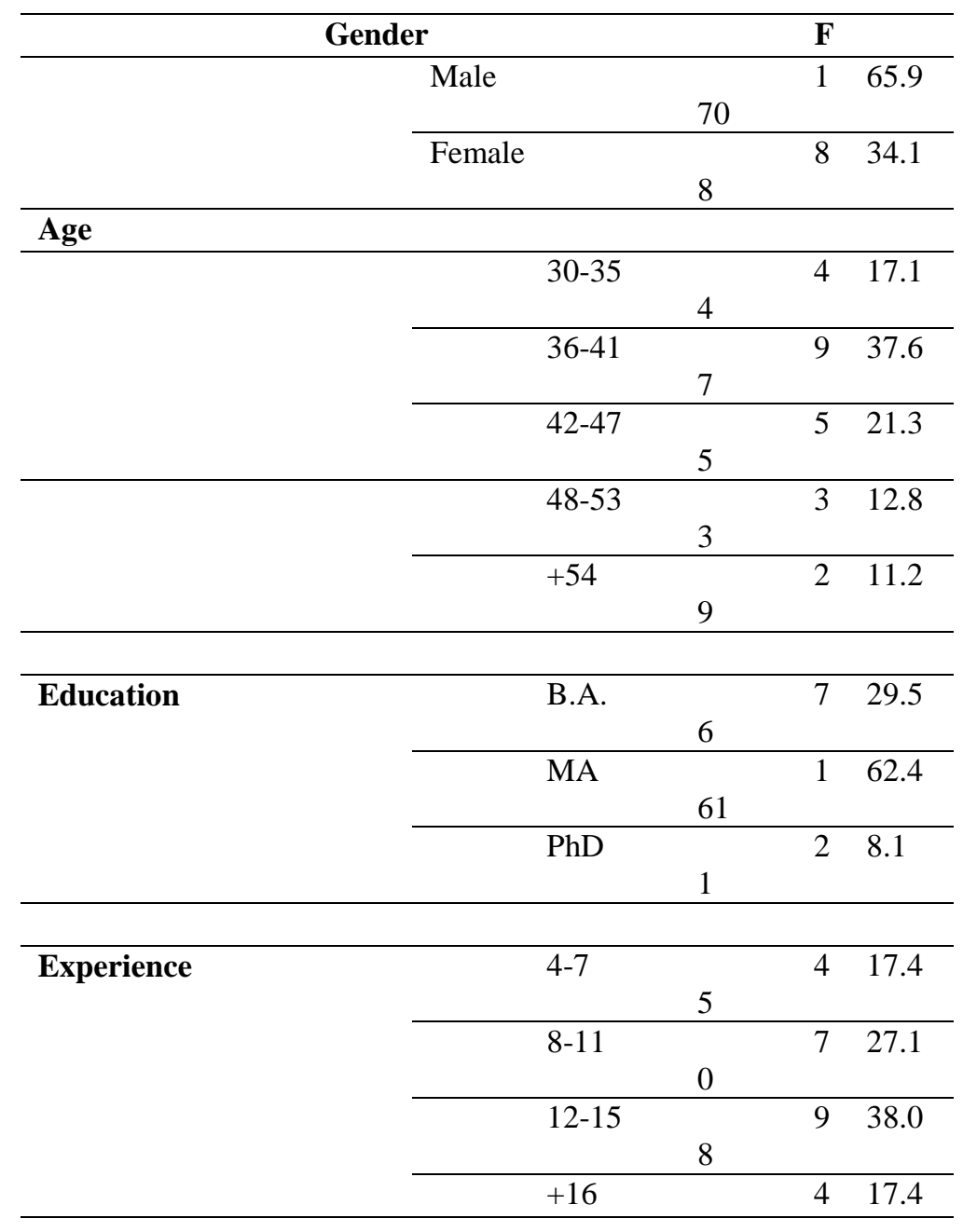




\begin{tabular}{lllll}
\hline & \multicolumn{4}{c}{5} \\
\cline { 2 - 4 } & Total & & 2 & 100.0 \\
& & 58 & & \\
\hline
\end{tabular}

\section{Questionnaire Analysis}

Statements of the questionnaire were analyzed following respondents' answers to the scale. As it appeared within the following table, the mean and standard deviation were calculated. It showed that respondents had positive attitudes towards questionnaire statements as all of them scored higher than the mean of scale 3.00. The most positively answered statements stemmed from the variables of (responsiveness). They were articulated "Employees have the green light to take any measures to satisfy customers" scoring a mean of (4.27) compared to the least positively answered questionnaire which stemmed from the variables of (employee empowerment) and articulated "Management and leadership use employee feedback to make improvements" scored a mean of (3.51).

Table 2: Descriptive Statistics of Questionnaire Statements

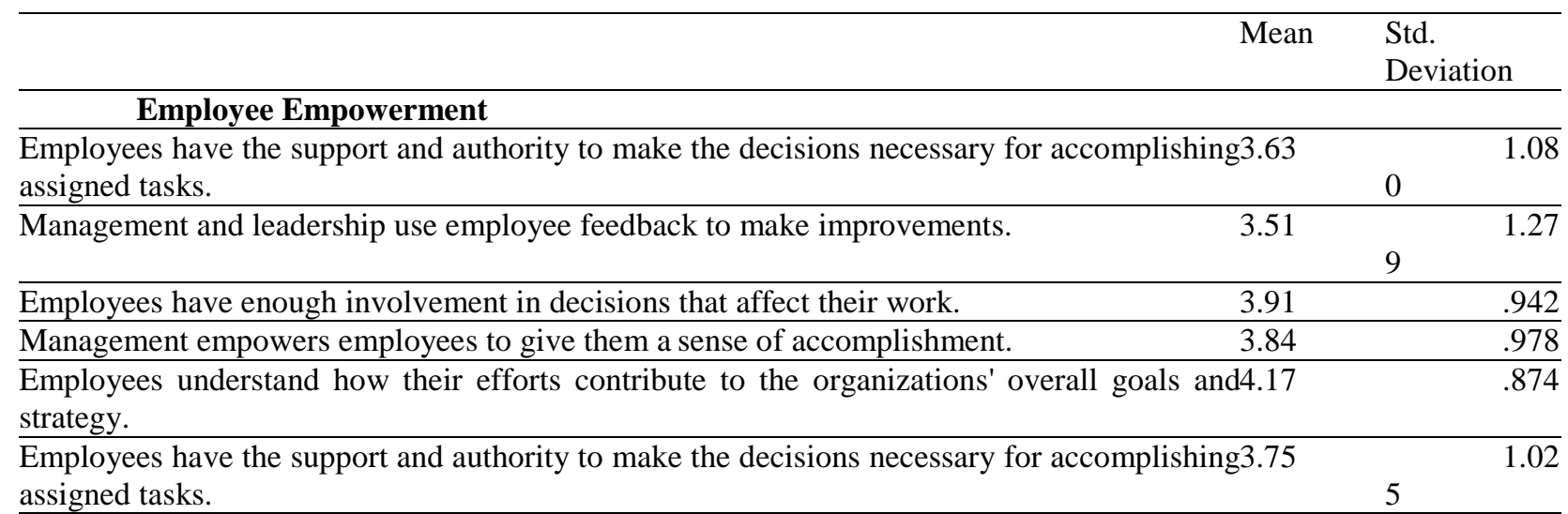

\section{Dimensions of Competitive Edge}

\section{Quality}

Quality is one of the significant employees' responsibilities

$4.01 \quad .828$

The issue of quality is clearly stated in the organizational mission and vision

4.04

.850

Al employees are directed towards achieving the highest quality

$4.14 \quad .832$

Many employees are asked to make prompt decisions to benefit quality

Quality is the main target for all employees

$4.04 \quad .850$

Responsiveness

Employees have the green light to take any measures to satisfy customers

All internal operations are dedicated to achieving added value to customers

Employees are trained to meet the needs and desires of customers at any price

Employees are trained to meet the needs and desires of customers at any price

$\begin{array}{lll}4.27 & .931 \\ 3.83 & 1.13\end{array}$

4.04

Employees are empowered to take prompt decision to satisfy customers

$3.66 \quad 9$

All employees have direct contact with customers to check the level of their satisfaction

3.66

\section{Innovation}

Employees are constantly exposed to training and workshops to develop their talents and skills 3.88

Brainstorming is a part of problem-solving sessions

3.81

Management supports innovative ideas from employees

4.09

Any supporting ideas are welcomed from employees

4.13

Management puts into perspective different abilities, skills, and talents of employees

3.95

Efficiency

Employees are supported with all tools that help them complete their tasks in an efficient way

Customer satisfaction surveys are launched to measure the efficiency of employees

1.13

\section{6}




\begin{tabular}{|c|c|c|c|}
\hline Employees are rewarded based on their efficiency & 3.97 & 5 & 1.01 \\
\hline An appraisal is a vivid part within the organization for good efficiency & 4.10 & & .749 \\
\hline $\begin{array}{l}\text { Efficiency is measured through customer satisfaction and the level of employees } \\
\text { empowerment }\end{array}$ & 4.20 & & 680 \\
\hline Ethical Leadership & & & \\
\hline Tasks are assigned to employees according to their specialty & 3.84 & & .941 \\
\hline Tasks are assigned to employee equally according to their abilities and experience & 3.99 & & .904 \\
\hline Leadership is always available to present any needed help & 3.55 & 1 & 1.02 \\
\hline Leadership makes sure that all employees are empowered to make the right decision & 4.05 & & .868 \\
\hline $\begin{array}{l}\text { Leadership would not assign tasks to employees if they explained their inability to complet } \\
\text { them }\end{array}$ & 3.69 & 1 & 1.00 \\
\hline Leadership is always aware of the necessity to empower employees & 4.08 & & .911 \\
\hline Empowerment makes employees feel like contributors & 4.00 & & .889 \\
\hline
\end{tabular}

\section{Descriptive Statistics of Variables}

Means of adopted variables - see figure 1 - were calculated in the following table; it appeared that (Efficiency) scored the highest mean (4.09/5.00), referring to it as the most positively answered variable of all and indicating that individuals had a positive attitude towards this variable more than others.

Table 3: Mean of Study Variables

\begin{tabular}{|c|c|}
\hline & Mean Std. Deviation \\
\hline \multicolumn{2}{|c|}{ Employee Empowerment 3.8043.72620 } \\
\hline Quality & $4.0651 \quad .72107$ \\
\hline Responsiveness & 3.8907 .59282 \\
\hline Innovation & 3.9744 .61357 \\
\hline Efficiency & $\begin{array}{lll}4.0930 & .59782\end{array}$ \\
\hline Competitive Edge & $4.0058 \quad .53211$ \\
\hline Ethical Leadership & 3.8859 .67299 \\
\hline
\end{tabular}

\section{Validation of the Model}

Before starting structural analysis, the proposed study model must be validated by a set of indicators to check the suitability of the model of this study, as follows:

Table 4: Fit Model

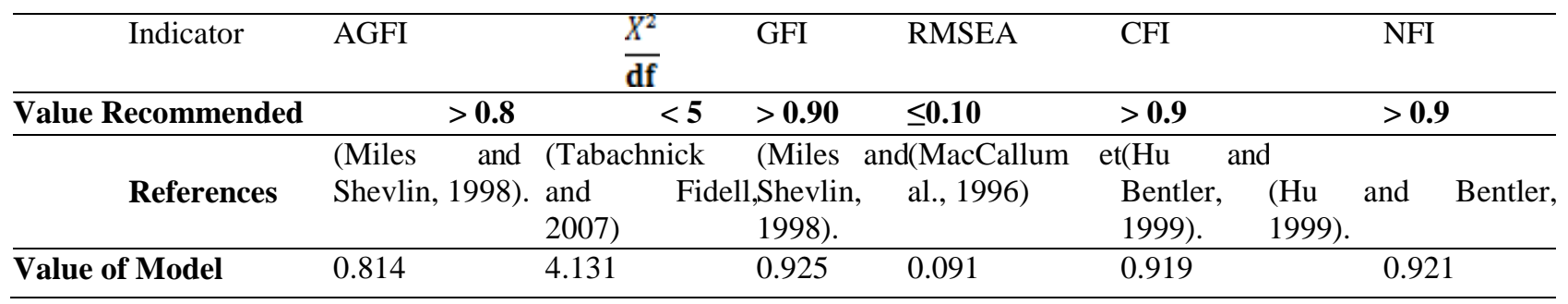

The results in Table 4 showed that the above indicators had passed the values recommended by the relevant references, this leads to the hypothesis testing:

\section{Hypotheses Testing}

Table 5: Results of Testing Hypotheses

\begin{tabular}{lccccc}
\hline & & Direct effect & Indirect effect & Total effectC.R. & decision \\
\hline Ethical & & Empowerment & 0.885 & 11.043 & accept \\
Leadership & --- & & & & $*$ \\
\hline
\end{tabular}




\begin{tabular}{lllllll}
\hline $\begin{array}{l}\text { Competitive } \\
\text { Edge }\end{array}$ & Empowerment & 0.393 & 0.422 & 0.815 & 5.309 & accept \\
\hline $\begin{array}{l}\text { Competitive } \\
\text { Edge }\end{array}$ & & & & & \\
& & & & & & \\
\end{tabular}

\section{$\mathrm{H}_{1}$ : employee empowerment can influence competitive edge}

Above table shows that $($ C.R. $=5.309 ; \mathrm{P}<0.05 ;=0.000)$. This means that employee empowerment can influence competitive edge

\section{$\mathrm{H}_{2}$ : employee empowerment can influence Ethical Leadership}

Above table shows that $($ C.R. $=11.043 ; \mathrm{P}<0.05 ;=0.000)$. This means that employee empowerment has the ability to influence Ethical Leadership

\section{$\mathrm{H}_{3}$ : Ethical Leadership has the ability to influence competitive edge}

Above table shows that $($ C.R. $=8.718 ; \mathrm{P}<0.05 ;=0.000)$. This means that employee empowerment has the ability to influence competitive edge

\section{$\mathrm{H}_{4}$ : Ethical leadership mediates the relationship between employee empowerment and competitive edge}

Above table shows that (Total effect $=0.815 ; \mathrm{P}<0.05 ;=0.000)$. This means that Ethical leadership mediates the relationship between employee empowerment and competitive edge.

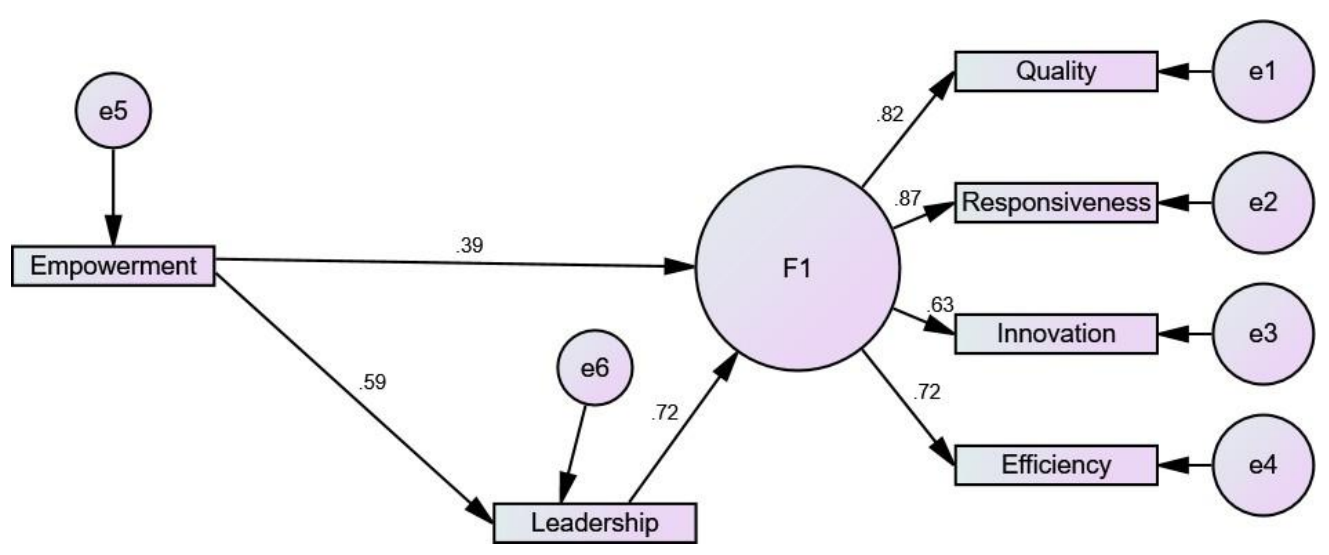

Figure 2: AMOS Output

\section{DISCUSSION}

The current study aimed to examine the impact of employee empowerment on reaching a better level of competitive edge through the mediating influence of ethical leadership. Dimensions of competitive edge were employed, including (quality, responsiveness, innovation, and efficiency). A quantitative approach was adopted to realize the main aim of the study. A questionnaire was employed to gather data from (258) individuals within Pakistani commercial banks. The study was able to reach the following results:

- Respondents had high awareness of study variables. All their responses scored higher than the mean of scale, which indicated a valid command and understanding from their side on the presented statements.

- Employee empowerment has the ability to influence a competitive edge.

- Employee empowerment has the ability to influence Ethical Leadership.

- Employee empowerment has the ability to influence a competitive edge.

- Ethical leadership mediates the relationship between employee empowerment and competitive edge.

The study proved that the prevailing leadership style and the philosophy pursued by the management in its dealings with its employees have a significant impact on the level of creativity of the workers, and there is no doubt that the creative capabilities of the subordinates are affected by the prevailing leadership style in their institutions. Based on the results of the study, in addition to the opinions of Kadhim et al. (2018); Safari et al. (2020), and Khan and Anjum (2013), it has 
been proven that an ethical leader can contribute to developing the creative capabilities of employees by empowering and encouraging them in solving problems and addressing them and presenting their solutions openly to them based on the basics of empowerment enjoyed by the employees in the organization. Consequently, the individual's awareness by the leadership of the importance of the role that he plays in the administrative process and the provision of opportunities for him through empowerment and development is among the motivating factors that push the individual to more effort, giving creativity.

The study was also able to clarify that efficiency and service quality are among the aspects that are influenced by empowerment that are supported with ethical leadership, as was agreed on by Gautam and Ghimire (2017). As it was seen through analysis that both quality and efficiency scored the highest means indicating that they were the most positively answered variables of all and referring to the fact that leadership does mediate the relationship between empowerment and competitive edge. This was agreed on by Javed et al. (2017) when they argued that ethical leadership supports employees' organizational identification, and at the same time plays a role in defining a better image for the organization before the employees, this leads to igniting a feeling within individuals that they are essential for their organization, they are essential, and their existence means a big idea which came along also with Al-Zoubi (2012) and Phangestu (2020) As a resultShafique et al. (2019) - employees begin to put better efforts, and present higher performance to realize organizational strategies and turn its goals into actual results. On the same track, the current study appeared to meet with what came along with Duan et al. (2018), who argues that ethical leadership is one of the aspects that influence employees creativity leading them to make more creative decisions and brainstorm ideas that would be an added value to the operations of the organization.

\section{CONCLUSION AND RECOMMENDATIONS}

By shedding light on empowerment and its impact on the competitive edge, and the overlap of the ethical leadership relationship with these two variables, it has been proven that empowerment depends on the type and style of leadership that is adopted, empowering employees in the wrong way and without conscious leadership guidance, in addition to granting empowerment. As if it is a prize for the employee, it is considered a form of empowerment that is out of place, given that conscious leadership is most able to choose the most efficient, better, and cheerful employees in terms of an impact compared to others.

From here, it can be said that it is correct to rely on the employee's expertise and skills before empowering. Still, the conscious moral leadership and the ethical leader who considers the interests of the employees and the organization together are the most capable of reaching positive results of empowerment centered around increasing the competitive edge first and last.

Based on previous discussion and conclusion of the study, it is recommended:

- Redesigning work to achieve job enrichment through qualifying and training courses to raise the level of employee skills.

- They were encouraging workers to submit proposals that impact developing their skills and expanding their field of empowerment compared to the previous stage.

- They were giving workers who have proven ability and skill the opportunity to participate in decision-making, which enhances their skills and paves the way for them to develop further in their empowerment at a later time.

\section{LIMITATIONS}

The authors examined the impact of employee empowerment on competitive edge through the mediating role of ethical leadership. There are, however, some moderating and mediating variables that may help bridge the gap between employee empowerment and competitive edges, like technological advancement and information management capabilities, and technological innovation. Furthermore, the mediating or moderating role of leadership styles like servant leadership, transformational leadership, or transactional leadership could analyze the association between employee empowerment and competitive edge.

\section{AUTHORS' CONTRIBUTIONS}

Mahboob Ullah: Data Analysis and its interpretation, Abstract and Conclusion writing, review of the article after completion, and correspondence with the journal.

Muhammad Azizullah Khan: Data Collection, working on Literature and after completion of research, its review.

\section{REFERENCES}

1. ALQershi, N., Ismail, A. I., Abualrejal, H., \& Salahudin, S. N. (2020). Competitive advantage achievement through customer relationship management dimensions. The Journal of Distribution Science, 18(11), 61-67.

2. Altarawneh, I. (2017). Effect of intellectual capital on competitive advantage in the Jordanian pharmaceutical companies. European Journal of Business and Management, 9(5), 39-53. 
3. Al-Zoubi, M. R. (2012). Leadership competencies and competitive advantage: Empirical study on Jordan telecommunications. European Journal of Business and Management, 4(7), 234-247.

4. Al-Zwaylif, I. M., \& Taher, L. (2020). The effect of the six sigma approach as a tool for strategic cost management on achieving competitive advantage: the case of Jordanian industrial, public shareholding companies. International Journal of Six Sigma and Competitive Advantage, 12(2- 3), 120-135. https://doi.org/10.1504/IJSSCA.2020.10032984

5. Amer, R. S., \& Abdulwahhab, F. L. (2020). Achieving the competitive advantage by using Customer Relationships Management (CRM). Polish Journal of Management Studies, 21(2), 97-105. https://doi.org/10.17512/pjms.2020.21.1.05

6. Andi Kele, A. T. (2020). Employee empowerment in luxury hotels in East Malaysia (Doctoral dissertation, The University of Waikato).

7. Andika, R., \& Darmanto, S. (2020). The Effect of Employee Empowerment and Intrinsic Motivation on Organizational Commitment and Employee Performance. Jurnal Aplikasi Manajemen, 18(2), 241-251. https://doi.org/10.21776/ub.jam.2020.018.02.04

8. Asif, M., Qing, M., Hwang, J., \& Shi, H. (2019). Ethical leadership, affective commitment, work engagement, and creativity: Testing a multiple mediation approach. Sustainability, 11(16), 4489. https://doi.org/10.3390/su11164489

9. Baird, K., Tung, A., \& Su, S. (2020). Employee empowerment, performance appraisal quality, and performance. Journal of Management Control, 6(3), 1-24.

10. Bani-Melhem, S., Quratulain, S., \& Al-Hawari, M. A. (2020). Customer incivility and frontline employees' revenge intentions: interaction effects of employee empowerment and turnover intentions. Journal of Hospitality Marketing \& Management, 29(4), 450-470. https://doi.org/10.1080/19368623.2019.1646180

11. Bavik, Y. L., Tang, P. M., Shao, R., \& Lam, L. W. (2018). Ethical leadership and employee knowledge sharing: Exploring dual-mediation paths. The Leadership Quarterly, 29(2), $322-332$. https://doi.org/10.1016/i.leaqua.2017.05.006

12. Bello, S. M. (2012). Impact of ethical leadership on employee job performance. International Journal of Business and Social Science, 3(11), 166-175.

13. Bharadwaj, D., Farooq, A., \& Jena, B. N. (2017). Value Discipline Dimensions on Organisational Performance and Competitive Advantage: A Study on Pharmaceutical Companies in Diabetes Care. International Journal of Marketing Studies, 9(3), 88-102. https://doi.org/10.5539/ijms.v9n3p88

14. Cantele, S., \& Zardini, A. (2018). Is sustainability a competitive advantage for small businesses? An empirical analysis of possible mediators in the sustainability-financial performance relationship. Journal of Cleaner Production, 182, 166-176. https://doi.org/10.1016/j.jclepro.2018.02.016

15. Chengwu, S. U. N. (2020). The Research and Evaluation of Customer Relationship Management and Social Responsibility on Competitive Advantage. Revista de Cercetare si Interventie Sociala, 69. https://doi.org/10.33788/rcis.69.8

16. Ciurea, S. (2017). Dimensions of Innovation as Competitive Advantage in Romanian Enterprises. Ecoforum Journal, 6(3), 203-212.

17. Duan, S., Liu, Z., \& Che, H. (2018). Mediating influences of ethical leadership on employee creativity. Social Behavior and Personality: an international journal, 46(2), 323-337. https://doi.org/10.2224/sbp.6160

18. Duan, S., Liu, Z., \& Che, H. (2018). Mediating influences of ethical leadership on employee creativity. Social Behavior and Personality: an international journal, 46(2), 323-337. https://doi.org/10.2224/sbp.6160

19. Duffett, R., Edu, T., Haydam, N., Negricea, I. C., \& Zaharia, R. (2018). A multi-dimensional approach of green marketing competitive advantage: a perspective of small medium and micro enterprises from Western Cape, South Africa. Sustainability, 10(10), 3764. https://doi.org/10.3390/su10103764

20. Dust, S. B., Resick, C. J., Margolis, J. A., Mawritz, M. B., \& Greenbaum, R. L. (2018). Ethical leadership and employee success: Examining the roles of psychological empowerment and emotional exhaustion. The Leadership Quarterly, 29(5), 570-583. https://doi.org/10.1016/j.leaqua.2018.02.002

21. Dust, S. B., Resick, C. J., Margolis, J. A., Mawritz, M. B., \& Greenbaum, R. L. (2018). Ethical leadership and employee success: Examining the roles of psychological empowerment and emotional exhaustion. The Leadership Quarterly, 29(5), 570-583. https://doi.org/10.1016/j.leaqua.2018.02.002

22. Engelbrecht, A. S., Heine, G., \& Mahembe, B. (2017). Integrity, ethical leadership, trust, and work engagement. Leadership \& Organization Development Journal, 38(3), 368-379. https://doi.org/10.1108/LODJ11-2015-0237

23. Feng, T., Wang, D., Lawton, A., \& Luo, B. N. (2019). Customer orientation and firm performance: The joint moderating effects of ethical leadership and competitive intensity. Journal of Business Research, 100, 111-121. https://doi.org/10.1016/j.jbusres.2019.03.021

24. Gautam, D. K., \& Ghimire, S. B. (2017). Psychological empowerment of employees for competitive advantages. International Journal of Law and Management, 10(2), 33-47.

25. Hurmelinna-Laukkanen, P., Olander, H., \& Von Zedtwitz, M. (2018). The nature and dimensions of knowledge mobility for competitive advantage. In Knowledge Management in the Sharing Economy (pp. 169188). Springer, Cham. https://doi.org/10.1007/978-3-319-66890-1_9 
26. Ivanova, M., \& von Scheve, C. (2020). Power through empowerment? The managerial discourse on employee empowerment. Organization, 27(6), 777-796. https://doi.org/10.1177/1350508419855709

27. Javed, B., Khan, A. A., Bashir, S., \& Arjoon, S. (2017). Impact of ethical leadership on creativity: the role of psychological empowerment. Current Issues in Tourism, 20(8), 839-851. https://doi.org/10.1080/13683500.2016.1188894

28. Javed, B., Khan, A. A., Bashir, S., \& Arjoon, S. (2017). Impact of ethical leadership on creativity: the role of psychological empowerment. Current Issues in Tourism, 20(8), 839-851. https://doi.org/10.1080/13683500.2016.1188894

29. Javed, B., Rawwas, M. Y., Khandai, S., Shahid, K., \& Tayyeb, H. H. (2018). Ethical leadership, trust in leader and creativity: The mediated mechanism and an interacting effect. Journal of Management \& Organization, 24(3), 388-405. https://doi.org/10.1017/jmo.2017.56

30. Jocelyne, S., \& Kariuki, M. (2020). Human capital, employee empowerment, and organization performance. International Academic Journal of Human Resource and Business Administration, 3(9), 319-332.

31. Jones, T. M., Harrison, J. S., \& Felps, W. (2018). How applying instrumental stakeholder theory can provide a sustainable competitive advantage. Academy of Management Review, 43(3), 371- 391. https://doi.org/10.5465/amr.2016.0111

32. Kadhim, R., Mohammed, M., \& Gremikh, H. (2018). Empowerment as a strategy to achieve the competitive advantage of organizations: A mediating role of organizational learning. Management Science Letters, 8(9), 903-912. https://doi.org/10.5267/j.msl.2018.6.008

33. Kahreh, M. S., Ahmadi, H., \& Hashemi, A. (2011). Achieving competitive advantage through empowering employees: An empirical study. Far East Journal of Psychology and Business, 3(2), 26-37.

34. Kalashi, M., Azizi, B., Bakhshalipour, V., \& Sareshkeh, S. K. (2020). The relationship between knowledge management process on information and communication technology dimensions and competitive advantage in physical education faculties. EUREKA: Social and Humanities, (6), 3-11. https://doi.org/10.21303/2504$\underline{5571.2020 .001535}$

35. Kaleka, A., \& Morgan, N. A. (2017). Which competitive advantage (s)? Competitive advantage-market performance relationships in international markets. Journal of International Marketing, 25(4), 25-49. https://doi.org/10.1509/jim.16.0058

36. Khan, R., ur Rehman, Z., Ahmed, M. S., \& Rahman, A. (2020). Employee Empowerment and Its Influence on Employee Performance: A Case of Hazara University. Sarhad Journal of Management Sciences, 6(1), 1-14.

37. Khan, S., \& Anjum, M. A. (2013). Role of leadership style and its impact on getting competitive advantage. European Journal of Applied Sciences, 5(2), 53-61.

38. Kiyabo, K., \& Isaga, N. (2020). Entrepreneurial orientation, competitive advantage, and SMEs' performance: application of firm growth and personal wealth measures. Journal of Innovation and Entrepreneurship, 9(1), 115. https://doi.org/10.1186/s13731-020-00123-7

39. Kiyabo, K., \& Isaga, N. (2020). Entrepreneurial orientation, competitive advantage, and SMEs' performance: application of firm growth and personal wealth measures. Journal of Innovation and Entrepreneurship, 9(1), 115. https://doi.org/10.1186/s13731-020-00123-7

40. Kusumadewi, R., \& Karyono, O. (2019). Impact of Service Quality and Service Innovations on Competitive Advantage in Retailing. Budapest International Research and Critics Institute-Journal (BIRCI-Journal), 2(2), 366-74. https://doi.org/10.33258/birci.v2i2.306

41. Mahasneh, M. M., Alnahdi, S. A., \& Bani Hani, J. S. (2020). Innovation in health services alignment with the competitive advantage achievement in private hospitals in Saudi Arabia: Strategic evidence. International Journal of Business and Social Science, 11(3), 58-68. https://doi.org/10.30845/ijbss.v11n3a8

42. Minbaeva, D. B. (2018). Building credible human capital analytics for organizational competitive advantage. Human Resource Management, 57(3), 701-713. https://doi.org/10.1002/hrm.21848

43. Mohammed, W. M., Weli, A. S., \& Ismael, F. M. (2019). Application of electronic commerce and competitive advantage: a case study of electrical appliances trading companies in Baghdad. J. Eng. Appl. Sci, 14(9), 30403052. https://doi.org/10.36478/jeasci.2019.3040.3052

44. Obi, C. N., Leggett, C., \& Harris, H. (2020). National culture, employee empowerment and advanced manufacturing technology utilization: A study of Nigeria and New Zealand. Journal of Management and Organization, 26(4), 460-482. https://doi.org/10.1017/jmo.2017.70

45. Pasricha, P., Singh, B., \& Verma, P. (2018). Ethical leadership, organic organizational cultures, and corporate social responsibility: An empirical study in social enterprises. Journal of Business Ethics, 151(4), 941-958. https://doi.org/10.1007/s10551-017-3568-5

46. Phangestu, J., Kountur, R., \& Prameswari, D. A. (2020). The Moderating Effect of Entrepreneurial Leadership and Competitive Advantage on the Relationship Between Business Model Innovation and Startup Performance. Journal of Business and Retail Management Research, 14(3), 221-236. https://doi.org/10.24052/JBRMR/V14IS03/ART-06

47. Ponnu, C. H., \& Tennakoon, G. (2009). The association between ethical leadership and employee outcomesthe Malaysian case. EJB-Electronic Journal of Business Ethics and Organization Studies. 14(1), 431-440.

48. Rahim, F. B. T., \& Zainuddin, Y. B. (2019, January). The impact of technological innovation capabilities on 
competitive advantage and firm performance in Malaysia's automotive industry. In AIP Conference Proceedings (Vol. 2059, No. 1, p. 020030). AIP Publishing LLC. https://doi.org/10.1063/1.5085973

49. Rashid, K. T. S., Ismael, D. A., Othman, B., \& Ali, R. (2019). Dimensions of service quality and their effects on achieving competitive advantage: An exploratory study of banking organizations in Sulaimaniyah city-Iraq. International Journal of Psychosocial Rehabilitation, 23(2), 548-565.

50. Rashid, K. T. S., Ismael, D. A., Othman, B., \& Ali, R. (2019). Dimensions of service quality and their effects on achieving competitive edge: An exploratory study of banking organizations in Sulaimaniyah city-Iraq. International Journal of Psychosocial Rehabilitation, 23(2), 548-565.

51. Saeidi, P., Saeidi, S. P., Sofian, S., Saeidi, S. P., Nilashi, M., \& Mardani, A. (2019). The impact of enterprise risk management on competitive advantage by moderating role of information technology. Computer Standards \& Interfaces, 63, 67-82. https://doi.org/10.1016/j.csi.2018.11.009

52. Safari, A., Adelpanah, A., Soleimani, R., Aqagoli, P. H., Eidizadeh, R., \& Salehzadeh, R. (2020). The effect of psychological empowerment on job burnout and competitive edge. Management Research: Journal of the Iberoamerican Academy of Management, 5(3), 147-162

53. Setyawati, S. M., Rosiana, M., \& Shariff, M. N. M. (2017). Competitive advantage as mediating variable on the relationship between innovation and business performance on SMEs in Purwokerto Province. Saudi Journal of Business and Management Studies, 2(7), 693-699.

54. Seyyed-Amiri, N. A. D. E. R., Shirkavand, S., Chalak, M., \& Rezaeei, N. (2017). Competitive intelligence and developing sustainable competitive advantage. AD-minister, (30), 173-194. https://doi.org/10.17230/administer.30.9

55. Shafique, I., Ahmad, B., \& Kalyar, M. N. (2019). How ethical leadership influences creativity and organizational innovation. European Journal of Innovation Management, 23(1), 114-133. https://doi.org/10.1108/EJIM-12-2018-0269

56. Sulaiman, N. A., \& Muhamad, R. (2020). CSR and Employee Empowerment: Scale Development and Validation. Academic Journal of Business and Social Sciences, 4(1), 1-13.

57. Tsai, P. H., \& Lin, C. T. (2018). How should national museums create a competitive advantage following changes in the global economic environment?. Sustainability, 10(10), 3749. https://doi.org/10.3390/su10103749

58. Ullah, M., Afghan, N., Afridi, A.S. (2019). Effects of Corporate Governance on Capital Structure and Financial Performance: Empirical Evidence from Listed Cement Corporations in Pakistan. Global Social Sciences Review. 4(3), 273-283. https://doi.org/10.31703/gssr.2019(IV-III).25

59. Wahyuningsih, S. H., Sudiro, A., Troena, E. A., \& Irawanto, D. (2019). Analysis of organizational culture with Denison's model approach for international business competitiveness. Problems and perspectives in management, (17, Iss. 1), 142-151. https://doi.org/10.21511/ppm.17(1).2019.13

60. Weidenstedt, L. (2020). Employee Empowerment and Paternalism: A Conceptual Analysis of Empowerment's Embeddedness in Communicative Contexts. mrev management revue, 31(4), 444-464. https://doi.org/10.5771/0935-9915-2020-4-444

61. Yang, Q., \& Wei, H. (2017). Ethical leadership and employee task performance: Examining moderated mediation process. Management Decision, 55(7), 1506-1520. https://doi.org/10.1108/MD-09-2016-0627

62. Yeşiltaş, M., \& Tuna, M. (2018). The effect of ethical leadership on service sabotage. The Service Industries Journal, 38(15-16), 1133-1159. https://doi.org/10.1080/02642069.2018.1433164

63. Yin, Y. (2020). What determines the adoption of employee empowerment practices by MNE subsidiaries in China?. Chinese Management Studies, 14(4), 871-894. https://doi.org/10.1108/CMS-09-2019-0340

64. Zhao, H., \& Xia, Q. (2019). Nurses' negative affective states, moral disengagement, and knowledge hiding: The moderating role of ethical leadership. Journal of nursing management, 27(2), 357-370. https://doi.org/10.1111/jonm.12675 